Analytical Methods

\title{
Characterization of cider by its hydrophobic protein profile and foam parameters
}

\author{
Domingo Blanco-Gomis $^{\mathrm{a}, *}$, Juan J. Mangas-Alonso ${ }^{\mathrm{b}}$, Yoana Expósito-Cimadevilla ${ }^{\mathrm{a}, *}$, \\ $\mathrm{M}^{\mathrm{a}}$ Dolores Gutiérrez-Álvarez ${ }^{\mathrm{a}}$ \\ ${ }^{a}$ Departamento de Química Física y Analítica, Facultad de Química, Universidad de Oviedo, Julián Clavería 8, E-33006 Oviedo, Asturias, Spain \\ ${ }^{\text {b }}$ Servicio Regional de Investigación y Desarrollo Agroalimentario (SERIDA), Ctra. Oviedo s/n, Apdo. 13, E-33300 Villaviciosa, Asturias, Spain
}

\section{A R T I C L E I N F O}

\section{Article history:}

Received 9 December 2008

Received in revised form 2 June 2009

Accepted 28 November 2009

\section{Keywords:}

Cider

Protein

RP-HPLC

Foam

Multivariate techniques

\begin{abstract}
A B S T R A C T
This paper describes the characterization of ciders (both "natural" and sparkling cider) from the Principality of Asturias (northwest region of Spain) through the analysis of their protein content, based on their hydrophobic properties, and their foam characteristics. A reversed-phase high performance liquid chromatography (RP-HPLC) was applied to the protein analysis, and the foam parameters were measured with Bikerman's method. Multivariate techniques allowed the authors to differentiate ciders on the basis of the press and foam taking technologies, and foam sensory quality. Feasible and robust models were constructed for classifying purposes. Higher than 95\% correct classifications were obtained for differentiating ciders on the basis of the factors studied (cider making technology and foam sensory quality). The multivariate regression model computed allowed the authors to predict (correlation coefficients higher than 0.8 ) the foam parameters related to foam stability and bubble average lifetime in "natural" cider.
\end{abstract}

(c) 2009 Elsevier Ltd. All rights reserved.

\section{Introduction}

Cider is a very important beverage in the Principality of Asturias (northwest region of Spain). Annual production is about 0.82 million $\mathrm{hl}$, and $55 \%$ of this production corresponds to "natural" cider. The rest of the cider production corresponds to a sparkling beverage made either by carbonation of cider or by the "Champenoise" technology.

Foam is a quality parameter of great relevance from a sensory viewpoint, since it is the first attribute that consumers perceive. Moreover, high and significant correlations between foam, odor and taste qualities in cider have been detected (data not published). Good foaming behavior in "natural" cider includes the initial formation of a large amount of foam when it is poured in the glass, followed by its rapid disappearance forming little bubbles of carbonic gas; finally a rest of thin foam should stay in the glass. The typical visual attributes assessed in sparkling cider are initial foam, foam area persistence, number of nucleation sites, bubble size, and foam collar (Picinelli Lobo, Fernández Tascón, Rodríguez Madrera, \& Suárez Valles, 2005).

Proteins contribute to form and stabilize foams. The important role of these molecules can be explained by their ability to decrease the interfacial tension, and increase the viscous and elastic properties of the film, as a result of the formation of hydrogen

\footnotetext{
* Corresponding authors. Tel.: +34 985 103490/89; fax: +34 985103125.

E-mail addresses: dbg@fq.uniovi.es (D. Blanco-Gomis), jjmangas@serida.org (J.J. Mangas-Alonso), yoana743@yahoo.es (Y. Expósito-Cimadevilla), loly@uniovi.es (MD. Gutiérrez-Álvarez).
}

bonds, and electrostatic and hydrophobic interactions (Zayas, 1997).

Different authors have carried out studies on base wines used for making sparkling wine (Andrés-Lacueva, López-Tamanes, Lamuela-Raventós, Buxaderas, \& De la Torre-Boronat, 1996; Brissonnet \& Maujean, 1993; Robillard et al., 1993) and they have shown the existence of a relationship between protein concentration and foam quality.

On the other hand, proteins can become a valuable "finger print" for characterizing fermented beverages, since these macromolecules are not influenced by the nature of the soil or the climate, but are genetically defined. In fact, different authors have analyzed wine and must protein fractions in order to characterize them (González-Lara, Correa, Polo, Martín-Álvarez, \& Ramos, 1989; Moreno-Arribas, Cabello, Polo, Martín-Álvarez, \& Pueyo, 1999; Polo et al., 1989).

Our research group has characterized both "natural" and sparkling cider on the basis of the molecular weight profile of polypeptides having found a close association between sensory foam quality, cider making technology and polypeptides nature. Thus, in the case of "natural" cider, low and middle molecular weight polypeptides were associated with good foaming properties, while the presence of higher molecular weight polypeptides is linked to the fast press manufacturing technology (Blanco Gomis, Mangas Alonso, Junco Corujedo, \& Gutiérrez Álvarez, 2007). On the other hand, in the case of sparkling cider manufacturing, the molecular weight of polypeptides was related to yeast type used in the foam generation step (Blanco Gomis, Mangas Alonso, Junco Corujedo, \& Gutiérrez Álvarez, 2009). 
Since hydrophobic interactions are a very important factor for foam forming and stabilizing, it is necessary to know the protein composition based on its hydrophobic character. Therefore, knowledge of the influence of cider making technology (for example, press and foam taking technologies) on protein hydrophobic profile and foam quality is a very important question in order to improve and to suitably control cider quality. Other technological factors, such as addition of fining agents or thermally extracted yeast cell wall, can have an effect on the foam quality in sparkling wine (García, Aleixandre, Álvarez, \& Lizama, 2009; Núñez, Carrascosa, González, Polo, \& Martínez-Rodríguez, 2006).

Due to protein structural complexity and the great variability that exists, the use of modern analytical techniques such as reversed-phase high performance liquid chromatography (RP-HPLC) is required for protein analysis. This analytical technique is specially appropriate for quantifying polypeptides on the basis of hydrophobic properties (Bobe, Beitz, Freeman, \& Lindberg, 1998; González \& González-Lara, 1993; González-Lara \& González, 1991; Knuutinen \& Harjula, 1998; Santoro, 1995; Trujillo, Casals, \& Guamis, 2000).

On the other hand, to carry out a study about cider foam is necessary to measure its foaming properties: Foam Height or foamability (FH), Foam Stability height (FS), a parameter related to bubble average lifetime and collar quality, and foam Stability Time (ST), a parameter related to the average lifetime of foam. These parameters have been positively correlated to descriptors evaluated in sensory analysis of sparkling wines as foam area, foam collar, and global impression (Gallart, Tomás, Suberbiola, LópezTamames, \& Buxaderas, 2004).

The goal of this study was to characterize both "natural" and sparkling cider based on the hydrophobic profile (Blanco Gomis, Expósito Cimadevilla, Junco Corujedo, \& Gutiérrez Álvarez, 2003) of polypeptides and foam properties (FH, FS, and ST). Chemometric techniques had to be applied to extract the information from a high number of observations obtained from the analytical measurements. Furthermore, with such number of analytical data, multivariate techniques are the most appropriate statistical methodologies for classifying purposes (Rodríguez-Nogales, García, \& Marina, 2006). For example, while clustering techniques are used for searching natural grouping in the database, principal component analysis (PCA) is used to detect correlations between observations (samples) and original variables, in order to reduce their number. Modeling methods such as Bayesean analysis and Soft Independent Modeling of Class Analogy (SIMCA) are appropriate statistical tools for classifying purposes, and Partial Least Square (PLS) regression allows to establish mathematical relationship between a set of predictor variables and response ones.

\section{Materials and methods}

\subsection{Ciders and foams}

"Natural" ciders ( $n=34)$ were supplied by several cellars from the Principality of Asturias. Cider was elaborated by sequential juice extraction of Asturian cider apple varieties, using either a hammer mill, mechanical or hydraulic basket presses (slow press technology, $n=16$ ) or pneumatic presses (fast press technology, $n=18$ ). Afterwards, the extracted apple must was fermented by wild microflora in stainless steel, fiber, and/or chestnut wood casks.

Sparkling ciders ( $n=29$ ) were elaborated ("méthode champenoise") in the "Sidra el Gaitero" cellar, in two vintages (2001$2002, n=14$, and 2002-2003, $n=15$ ). The procedure of elaboration of sparkling cider was as follows: Asturian cider apples were first washed and milled, afterwards the pulp was macerated for 9-
$12 \mathrm{~h}$, and finally it was pressed in an automated hydraulic press (Bucher-Guyer). Fermentation was conducted by wild microflora in stainless steel casks at $14-20^{\circ} \mathrm{C}$. When the first fermentation had ended, cider was matured until optimal sensory properties of cider (base cider) were achieved. Then, base cider was clarified through a ceramic microfilter of $0.22 \mu \mathrm{m}$ of pore size. In order to carry out the foam taking in bottle, $18 \mathrm{~g} / \mathrm{L}$ sucrose, $0.05 \%(\mathrm{w} / \mathrm{v})$ nutritive solution [ammonium sulfate $96 \%(\mathrm{w} / \mathrm{w})$, citric acid $3.3 \%$ $(\mathrm{w} / \mathrm{w})$, and thiamine $0.7 \%(\mathrm{w} / \mathrm{w})$ ], and $0.003 \%$ bentonite, used as fining agent, were added to the base cider. This cider was inoculated (2\%) with two yeast types: cider yeast (C6, Saccharomyces bayanus) belonging to SERIDA yeasts collection, and a commercial wine yeast (Levuline CHP, Saccharomyces cerevisiae). Finally, cider was bottled (bottles of 0.75 and $1.5 \mathrm{~L}$ ), and the second fermentation ( 1 month) and aging "surlie" was conducted at $12-15{ }^{\circ} \mathrm{C}$ during 16 months. Sampling was initiated in base cider (two samples in 2001-2002 vintage, and three samples in 2002-2003 vintage) and continued along the foam taking (two samples) and aging. During this last stage, 10 samples regularly distributed throughout 16 months of aging were taken.

\subsection{Foams}

Foam of "natural" cider was extracted following a procedure based on the method developed by Brissonnet and Maujean (1991): $250 \mathrm{~mL}$ of cider were added to a glass cylinder (diameter: $3.5 \mathrm{~cm}$; length: $38.0 \mathrm{~cm}$ ) with a glass-frit at the bottom (porosity $10 \mu \mathrm{m}$ ). Carbonic gas was sparged through the glass-frit at $6.0 \mathrm{~L} /$ $\mathrm{h}$. The foam goes up along the glass cylinder, reaches the top, and collapses. The foam collapsed is denominated cider foam. The fraction contained inside the column after carbon dioxide has been sparged through it is the remainder cider. It is the cider without a significant part of the foam.

\subsection{Sample preparation}

Cider $(40 \mathrm{~mL})$ was sonicated for $5 \mathrm{~min}$ to free the proteins and centrifuged at $3000 \mathrm{~g}$ for $40 \mathrm{~min}$ to eliminate solid substances. Afterwards cider was filtered at $4{ }^{\circ} \mathrm{C}$ through PVDF Durapore (Millipore) $0.22 \mu \mathrm{m}$ of pore size, and $15 \mathrm{~mL}$ of the filtrate were added to a PD-10 mini-column $(6 \times 2.5 \mathrm{~mL}$ void volume $)$ of Sephadex [Amersham Pharmacia Biotech (Uppsala, Sweden)] previously equilibrated with $25 \mathrm{~mL}$ of water. Subsequently elution of proteins was performed in each mini-column with water $(6 \times 3.5 \mathrm{~mL})$, and the eluted volume was concentrated in the rotary vacuum evaporator until dryness. Sample was reconstituted in $300 \mu \mathrm{L}$ of water.

\subsection{HPLC equipment and conditions}

HPLC analyses were performed on a Shimadzu HPLC system (Columbia, MD, USA) equipped with two LC-10AD pumps, a UVVis SPD-M10AD photodiode array detector, a Sil-10 AD automatic injector and a Gastor 150 LCD on-line degasificator.

A Supelcosil $C_{18}$ column [Teknokroma (Barcelona, Spain), $250 \times 4.6 \mathrm{~mm}$ id, $5 \mu \mathrm{m}$, with a pore size of $300 \AA]$ was used. A guard column was inserted to protect the analytical column. The analysis of cider samples was monitored at $220 \mathrm{~nm}$, and the absorption spectra were recorded between 190 and $370 \mathrm{~nm}$. The mobile phase was, as eluent A, water (obtained through Millipore Milli-Q system, Milford, MA, USA) with $0.1 \%$ trifluoroacetic acid (Romil, Loughborough, UK), and as eluent B, water/acetonitrile (HPLC-grade, Romil) 5:95 (v/v) with 0.1\% trifluoroacetic acid. HPLC elution was performed at a flow rate of $1 \mathrm{~mL} / \mathrm{min}$ and at $38^{\circ} \mathrm{C}$ in gradient mode. Percentage of eluent $\mathrm{B}$ ranged linearly from $0 \%$ to $50 \%$ for $45 \mathrm{~min}$ followed from $50 \%$ to $100 \%$ for $25 \mathrm{~min}$. Afterwards, the column was equilibrated with $100 \%$ A for 15 min before the fol- 
lowing analysis. All mobile phase solutions were filtered through $0.45 \mu \mathrm{m}$ membrane filter, and samples were filtered trough PVDF Durapore $^{\circledast}$ (Millipore) $0.45 \mu \mathrm{m}$ filters before chromatographic analysis (injected volume, $50 \mu \mathrm{L}$ ).

Polypeptides and acetonitrile gradient profile corresponding to two samples of cider ("natural" and sparkling ciders) is shown in Fig. 1. Polypeptides elute according to their hydrophobicity estimated by the \% acetonitrile.

\subsection{Foam properties measurement}

Bikerman's method (1938) was adapted to analyze foaming parameters in cider. A glass column of $50 \mathrm{~mL}(60 \times 1 \mathrm{~cm})$ fitted at the bottom with a sintered glass disc (pore size $10 \mu \mathrm{m}$ ) was used. Gas flow (carbon dioxide) was controlled by means of a pressure regulator. Ten milliliters of cider, previously degasified ( 2 min under vacuum and shaking) at $20^{\circ} \mathrm{C}$, were poured into the column. Carbon dioxide was sparged through cider at a flow rate of $30 \mathrm{~mL} /$ min. Maximum Foam Height (FH parameter) and Foam Stability height (FS parameter) were recorded maintaining a continuous flow of carbon dioxide; then, the $\mathrm{CO}_{2}$ flow was interrupted, and the time elapsed till all bubbles collapsed was measured (ST parameter). Before each experiment the column was washed with $10 \mathrm{~mL}$ ethanol 95\%, three times with $10 \mathrm{~mL}$ Milli-Q water, and finally with $25 \mathrm{~mL}$ of cider sample. The analyses were replicated three times.

\subsection{Database and statistics}

\subsection{1. "Natural" ciders}

The database used consisted of 34 rows of "natural" ciders and 42 columns of polypeptides (39) and foam parameters (3) [Foam Height (FH), Foam Stability height (FS) and foam Stability Time (ST)]. Ciders were categorized in four classes on the basis of the juice extraction technique used (fast vs. slow presses) and the visual aspect evaluation of foam attributes: "foam head", "foam emulsion", and "lacing" (good quality vs. neutral or bad quality). This evaluation was carried out by the suppliers of the samples. Eighteen ciders were included into the fast extraction category, and the rest $(n=16)$ into the slow extraction one. Sixteen ciders
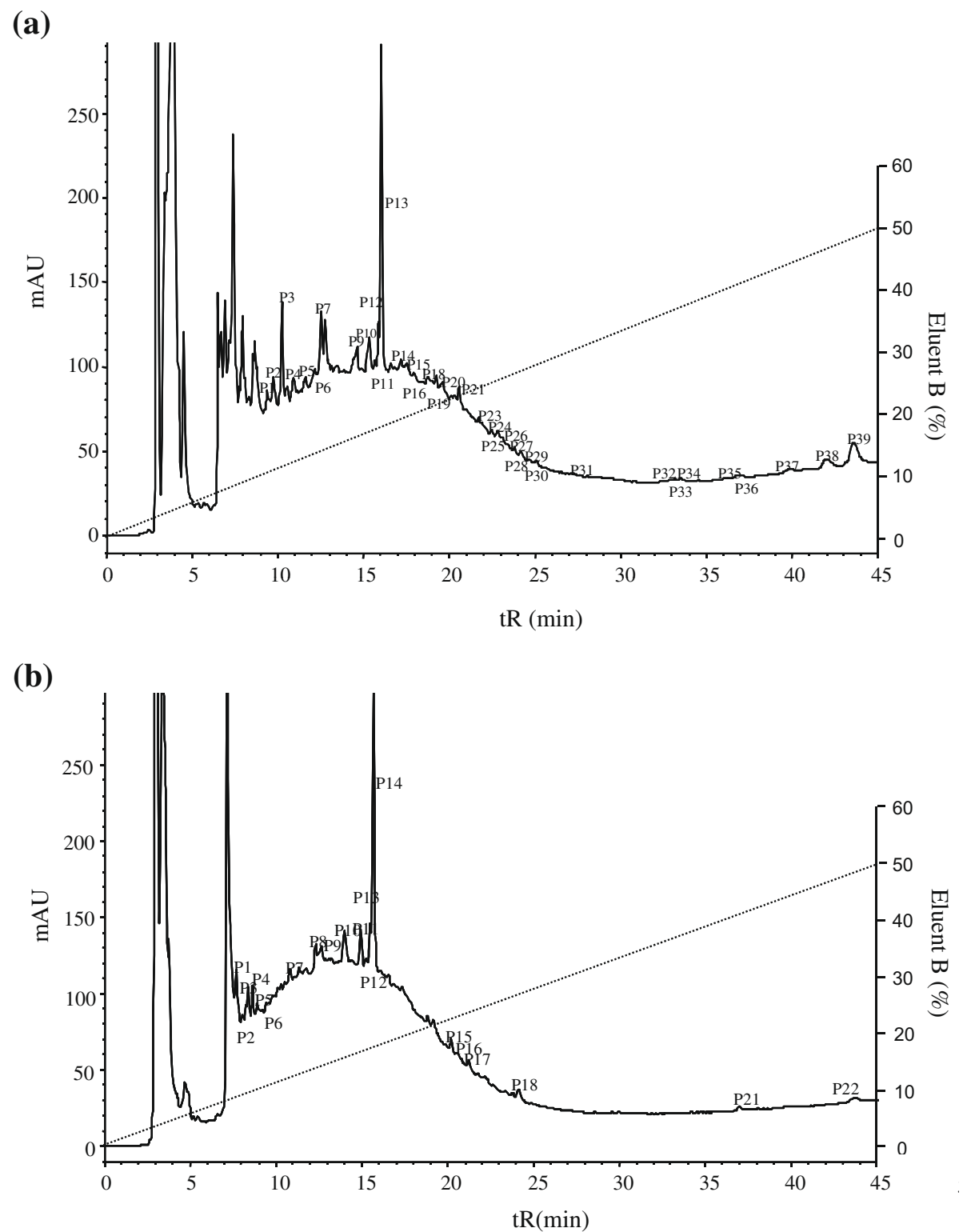

Fig. 1. Chromatogram of "natural” cider polypeptides (a) and sparkling cider polypeptides (b) recorded at 220 nm. For chromatographic conditions see Section 2. 
were categorized as good foaming quality and the other eighteen as neutral or bad foaming quality.

Table 1

Descriptive statistics of variables: (a) natural cider $(n=34)$, polypeptides and foam parameters (b) sparkling cider $(n=29)$, polypeptides.

\begin{tabular}{|c|c|c|c|c|}
\hline & Mean (area) & RSD (\%) & Max & Min \\
\hline \multicolumn{5}{|c|}{ Polypetides a } \\
\hline $\mathrm{P}_{1}$ & 37,674 & 61 & 101,611 & 7913 \\
\hline $\mathrm{P}_{2}$ & 55,350 & 70 & 136,565 & 3825 \\
\hline $\mathrm{P}_{3}$ & 165,728 & 69 & 398,947 & 11,428 \\
\hline $\mathrm{P}_{4}$ & 69,180 & 76 & 191,208 & 0 \\
\hline $\mathrm{P}_{5}$ & 35,916 & 68 & 93,394 & 0 \\
\hline $\mathrm{P}_{6}$ & 72,961 & 47 & 153,709 & 19,551 \\
\hline $\mathrm{P}_{7}$ & 136,016 & 47 & 308,106 & 34,138 \\
\hline $\mathrm{P}_{8}$ & 76,774 & 74 & 234,175 & 2597 \\
\hline $\mathrm{P}_{9}$ & 56,976 & 112 & 219,663 & 0 \\
\hline $\mathrm{P}_{10}$ & 188,168 & 72 & 532,712 & 15,009 \\
\hline $\mathrm{P}_{11}$ & 23,531 & 60 & 60,741 & 0 \\
\hline $\mathrm{P}_{12}$ & 52,823 & 118 & 195,770 & 0 \\
\hline $\mathrm{P}_{13}$ & 978,020 & 102 & $28,95,878$ & 0 \\
\hline $\mathrm{P}_{14}$ & 176,678 & 89 & 527,899 & 5615 \\
\hline $\mathrm{P}_{15}$ & 31,154 & 65 & 88,594 & 0 \\
\hline $\mathrm{P}_{16}$ & 26,186 & 111 & 98,189 & 0 \\
\hline $\mathrm{P}_{17}$ & 48,986 & 126 & 284,958 & 0 \\
\hline $\mathrm{P}_{18}$ & 45,466 & 116 & 209,139 & 0 \\
\hline $\mathrm{P}_{19}$ & 28,897 & 151 & 193,268 & 0 \\
\hline $\mathrm{P}_{20}$ & 20,349 & 108 & 92,637 & 0 \\
\hline $\mathrm{P}_{21}$ & 64,645 & 79 & 173,748 & 0 \\
\hline $\mathrm{P}_{22}$ & 17,666 & 154 & 84,003 & 0 \\
\hline $\mathrm{P}_{23}$ & 21,973 & 110 & 81,185 & 0 \\
\hline $\mathrm{P}_{24}$ & 16,484 & 102 & 60,722 & 0 \\
\hline $\mathrm{P}_{25}$ & 14,447 & 96 & 41,840 & 0 \\
\hline $\mathrm{P}_{26}$ & 11,554 & 134 & 56,192 & 0 \\
\hline $\mathrm{P}_{27}$ & 27,060 & 168 & 261,479 & 0 \\
\hline $\mathrm{P}_{28}$ & 24,840 & 158 & 168,563 & 0 \\
\hline$P_{29}$ & 13,955 & 141 & 63,753 & 0 \\
\hline $\mathrm{P}_{30}$ & 9821 & 145 & 44,331 & 0 \\
\hline $\mathrm{P}_{31}$ & 22,135 & 67 & 65,312 & 0 \\
\hline $\mathrm{P}_{32}$ & 2473 & 156 & 12,246 & 0 \\
\hline $\mathrm{P}_{33}$ & 1670 & 173 & 9156 & 0 \\
\hline $\mathrm{P}_{34}$ & 412 & 235 & 3309 & 0 \\
\hline $\mathrm{P}_{35}$ & 1942 & 170 & 10,355 & 0 \\
\hline $\mathrm{P}_{36}$ & 10,303 & 197 & 75,593 & 0 \\
\hline$P_{37}$ & 18,232 & 156 & 91,723 & 0 \\
\hline $\mathrm{P}_{38}$ & 26,051 & 184 & 181,647 & 0 \\
\hline$P_{39}$ & 211,653 & 142 & 902,429 & 0 \\
\hline \multicolumn{5}{|c|}{ Foam parameters } \\
\hline $\mathrm{FH}(\mathrm{cm})$ & 5.0 & 86.4 & 26.1 & 2.7 \\
\hline $\mathrm{FS}(\mathrm{cm})$ & 3.2 & 37.4 & 6.0 & 2.3 \\
\hline ST (s) & 17.4 & 55.1 & 37.7 & 9.5 \\
\hline \multicolumn{5}{|c|}{ Polypetides $b$} \\
\hline $\mathrm{P}_{1}$ & 92,719 & 80 & 335,820 & 15,659 \\
\hline $\mathrm{P}_{2}$ & 48,930 & 80 & 142,098 & 0 \\
\hline $\mathrm{P}_{3}$ & 31,004 & 101 & 117,082 & 0 \\
\hline $\mathrm{P}_{4}$ & 97,370 & 58 & 252,849 & 35,369 \\
\hline $\mathrm{P}_{5}$ & 68,662 & 56 & 114,916 & 11,652 \\
\hline $\mathrm{P}_{6}$ & 37,514 & 54 & 105,226 & 10,539 \\
\hline $\mathrm{P}_{7}$ & 59,461 & 21 & 82,465 & 32,669 \\
\hline $\mathrm{P}_{8}$ & 98,602 & 48 & 189,858 & 42,109 \\
\hline $\mathrm{P}_{9}$ & 35,479 & 49 & 76,836 & 11,149 \\
\hline $\mathrm{P}_{10}$ & 187,664 & 39 & 328,222 & 69,086 \\
\hline$P_{11}$ & 198,612 & 26 & 282,207 & 67,652 \\
\hline $\mathrm{P}_{12}$ & 22,868 & 28 & 41,712 & 14,124 \\
\hline $\mathrm{P}_{13}$ & 50,456 & 37 & 67,447 & 0 \\
\hline $\mathrm{P}_{14}$ & $12,45,522$ & 9 & $14,68,725$ & $10,21,809$ \\
\hline $\mathrm{P}_{15}$ & 68,340 & 54 & 148,728 & 10,962 \\
\hline $\mathrm{P}_{16}$ & 16,109 & 114 & 66,028 & 0 \\
\hline$P_{17}$ & 33,764 & 30 & 52,121 & 0 \\
\hline $\mathrm{P}_{18}$ & 71,084 & 45 & 122,044 & 28,015 \\
\hline $\mathrm{P}_{19}$ & 2471 & 387 & 44,969 & 0 \\
\hline$P_{20}$ & 3745 & 302 & 42,204 & 0 \\
\hline$P_{21}$ & 15,141 & 186 & 113,172 & 0 \\
\hline $\mathrm{P}_{22}$ & 55,870 & 73 & 162,713 & 0 \\
\hline
\end{tabular}

\subsubsection{Sparkling ciders}

The database consisted of 29 rows (sparkling ciders) and 22 columns (polypeptides). Ciders were categorized in two classes on the basis of the yeast type used in the foam taking step, either a cider yeast (Saccharomyces bayanus) vs. a wine one (Saccharomyces cerevisiae). Fifteen ciders were elaborated using S. bayanus strain (cider category, C), and fourteen were elaborated using S. cerevisiae (wine category, W).

Multivariate analyses (Cluster Analysis, Principal Component Analysis, Soft Independent Modeling of Class Analogy, Bayesean Analysis, and Partial Least Squares Regression) were carried out by means of PARVUS statistical package (Forina, Leardi, Armanino, \& Lanteri, 1988). Data were autoscaled before multivariate analysis. In order to decrease noise for the computing models more feasible and robust a reduction of the numbers of original variables was carried out. We used the univariate Fisher analysis, a Step Linear Discriminant Analysis (Step-LDA), and Pearson correlation between the original variables. The variables selected were chosen on the basis of maximizing both Fisher weight and discriminant power, and minimizing correlation coefficient among pairs of variables.

Table 1 lists the mean values and other descriptive statistics for each variable (polypeptides and foam parameters).

\section{Results and discussion}

\subsection{Exploratory analysis}

\subsection{1. "Natural" ciders}

The aim of the cluster analysis is to search for natural groupings among samples. Two possible variation sources could be detected in the database, press technology and foaming visual quality. In order to detect groupings among samples, two $34 \times 34$ matrices consisting of similarities of Manhattan distances and correlation coefficients, in which each observation was represented by a $42-$ dimensional vector (39 polypeptides plus three foam parameters), were used for hierarchical cluster analysis using the complete linkage and average linkage-weighted pair group methods, respectively. When Manhattan distances and complete linkage method were used for hierarchical cluster analysis, $94.4 \%$ of ciders belonging to "neutral or bad quality" category, and $69 \%$ of ciders belonging to "good foaming quality" were grouped at a similarity level of 0.145 . On the other hand, when correlation coefficient and average linkage-weighted pair group method were used for hierarchical cluster analysis, $81.3 \%$ of ciders belonging to "slow press technology" category were grouped at a similarity level of 0.464 , and $83.3 \%$ of ciders belonging to "fast press technology" were grouped in different clusters at $0.428,0.488,0.508$ and 0.638 similarities.

\subsubsection{Sparkling ciders}

In order to improve the search for natural groupings, previously to multivariate analysis, a variables selection was carried out. As a result, five polypeptides were selected $\left(\mathrm{P}_{1}, \mathrm{P}_{2}, \mathrm{P}_{3}, \mathrm{P}_{14}\right.$, and $\left.\mathrm{P}_{22}\right)$, so a new matrix constituted by 29 rows (sparkling ciders) and five columns (polypeptides).

One possible variation source could be detected in the database, namely the yeast type used in the foam taking step. In order to detect this variation source, a $29 \times 29$ matrix consisting of similarities of Manhattan distances, in which each observation was represented by a five-dimensional vector, was used for hierarchical cluster analysis, based on average linkage-weighted pair group method. At a similarity level of 0.569 three clusters included 93.3\% of sparkling ciders produced from S. bayanus strain.

In consequence, the exploratory analysis used allowed us to detect the variation sources related to foam quality and press tech- 
nology of "natural" ciders, and yeast type employed in foam taking step of sparkling ciders.

\subsection{Factor analysis of the internal structure}

\subsection{1. "Natural" ciders}

Principal component (PC) analysis was used to represent the forty two-dimensional data structure in a smaller number of dimensions in order to know the relationship between the variation sources (foaming quality and press technology) and the original variables (polypeptides and foam parameters), and to define the structure of the database. The following variables were selected: $\mathrm{P}_{2}, \mathrm{P}_{3}, \mathrm{P}_{7}, \mathrm{P}_{9}, \mathrm{P}_{13}, \mathrm{P}_{16}, \mathrm{P}_{25}, \mathrm{P}_{26}, \mathrm{P}_{38}$ and $\mathrm{P}_{39}$ for analyzing data structure based on the foaming quality of ciders, $P_{1}, P_{3}, P_{5}, P_{7}, P_{9}$, $\mathrm{P}_{10}$ and $\mathrm{P}_{38}$ for analyzing data structure based on the foaming quality of cider foam, and $\mathrm{P}_{6}, \mathrm{P}_{20}, \mathrm{P}_{25}, \mathrm{P}_{28}, \mathrm{P}_{36}, \mathrm{P}_{37}$ and $\mathrm{P}_{39}$ for analyzing data structure based on the press technology.

3.2.1.1. Internal structure based on the foaming quality. Three PCs that accounted for $72.4 \%$ of the variance were chosen on the basis of Kaiser's criterion (eigenvalues higher than 1). Fig. 2a presents the projection on the two first eigenvectors (60.5\% explained variance) of the cider samples and the original variables selected $\left(\mathrm{P}_{2}\right.$, $\mathrm{P}_{3}, \mathrm{P}_{7}, \mathrm{P}_{9}, \mathrm{P}_{13}, \mathrm{P}_{16}, \mathrm{P}_{25}, \mathrm{P}_{26}, \mathrm{P}_{38}$ and $\left.\mathrm{P}_{39}\right)$. As we can see all the ciders belonging to category 2 (neutral or bad quality) are placed on the right plane opposing polypeptides, with the exception of $\mathrm{P}_{25}$ and $\mathrm{P}_{26}$, what allows to visualize the positive influence on foaming quality of polypeptides with different hydrophobicity character, as for example $\mathrm{P}_{2}$ and $\mathrm{P}_{3}$ are hydrophilic polypeptides, while $\mathrm{P}_{38}$ and $\mathrm{P}_{39}$ have a hydrophobic character. As is well known hydrophobic residues influence on surface films properties. The most surface active protein and with more foamability capacity are the most hydrophobic, since have more molecular flexibility and capacity of unfolding, and the surface pressure is higher. Hydrophilic polypeptides can contribute to foam stability projecting polar loops that obstruct drainage and coalescence (Kinsella, 1981). Ciders with good foaming quality must have good foamability properties and to form small bubbles with a relative stability in order to obtain good lacing once the cider is drunk. At the same time, foam formed upon liquid surface must break quickly which can be favored by the presence of small surfactants, as fatty acids (Wilde, Husband, Cooper, \& Ridout, 2003), and the absence of polysaccharides that can form strong interactions with proteins and viscoelastic films (Mangas, Moreno, Rodríguez, Picinelli, \& Suárez, 1999; Schmitt, Sánchez, Desobry-Banon, \& Hardy, 1998).

The analysis of foam cider confirmed the results obtained in the protein analysis in cider. When foams and polypeptides selected $\left(\mathrm{P}_{1}, \mathrm{P}_{3}, \mathrm{P}_{5}, \mathrm{P}_{7}, \mathrm{P}_{9}, \mathrm{P}_{10}\right.$ and $\left.\mathrm{P}_{38}\right)$ are projected on the plane formed by the first and the third significant factors (percentage of variance explained 59.8\%), all cider foams belonging to neutral or bad category presented the highest negative scores for the first factor, and the greater part of the polypeptides (specially, $\mathrm{P}_{1}, \mathrm{P}_{3}, \mathrm{P}_{9}, \mathrm{P}_{10}$, and $P_{38}$ ) presented positive loadings for the first principal component. Furthermore, the quantity of hydrophobic polypeptides in foam was higher than in the cider without foam (data not shown), which is in accordance with the results obtained by Brissonnet and Maujean (1993) in Champagne.

3.2.1.2. Internal structure based on the press technology. Two PCs that accounted for $58.7 \%$ of the variance were chosen on the basis of Kaiser's criterion. Fig. $2 \mathrm{~b}$ presents the projection on the two first eigenvectors of the cider samples and the original variables selected $\left(\mathrm{P}_{6}, \mathrm{P}_{20}, \mathrm{P}_{25}, \mathrm{P}_{28}, \mathrm{P}_{36}, \mathrm{P}_{37}\right.$ and $\left.\mathrm{P}_{39}\right)$. As we can see all the ciders belonging to category 1 (slow press technology) are placed on the left plane opposing polypeptides with higher hydrophobic charac-
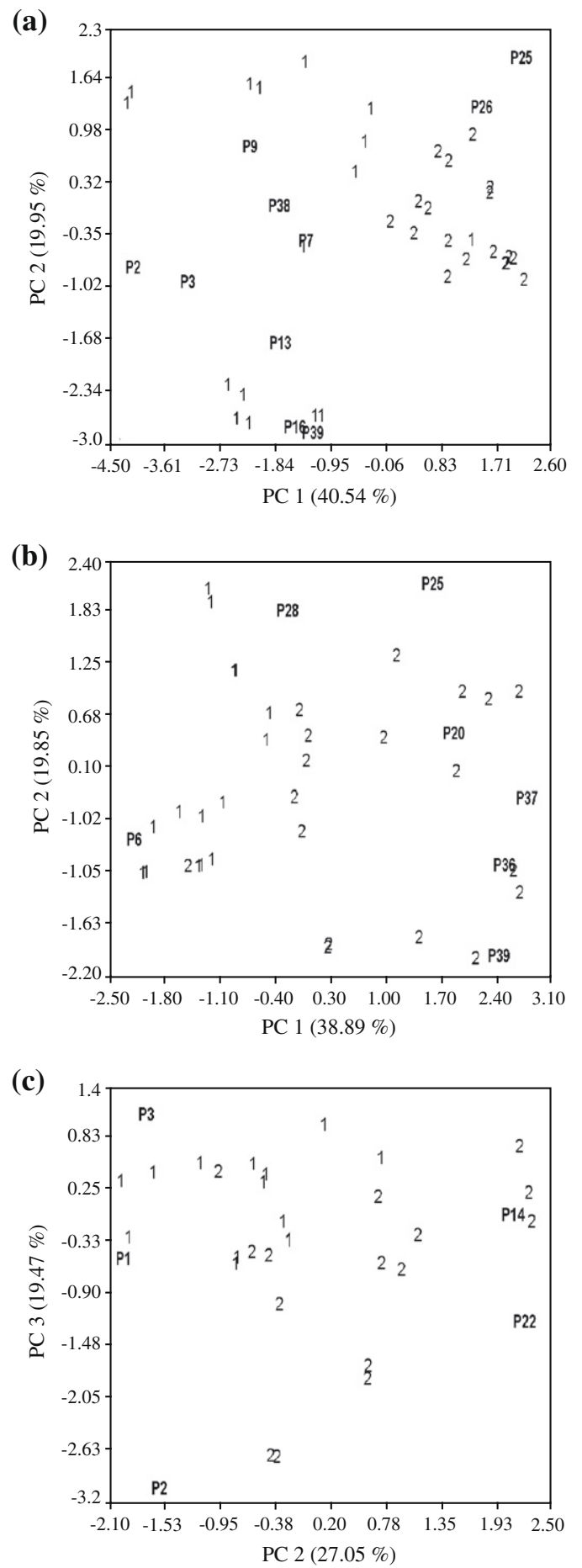

Fig. 2. (a) Eigenvector (first and second principal components) projection of the "natural" ciders and polypeptides selected $\left(\mathrm{P}_{2}, \mathrm{P}_{3}, \mathrm{P}_{7}, \mathrm{P}_{9}, \mathrm{P}_{13}, \mathrm{P}_{16}, \mathrm{P}_{25}, \mathrm{P}_{26}, \mathrm{P}_{38}\right.$ and $\left.P_{39}\right)$. Grouping 1 : cider with good quality $(n=16)$; grouping 2 : cider with neutral or bad quality $(n=18)$. (b) Eigenvector (first and second principal components) projection of the "natural" ciders and polypeptides selected $\left(\mathrm{P}_{6}, \mathrm{P}_{20}, \mathrm{P}_{25}, \mathrm{P}_{28}, \mathrm{P}_{36}, \mathrm{P}_{37}\right.$ and $\left.P_{39}\right)$. Grouping 1: cider made from slow press technology $(n=16)$; grouping 2 : cider made from fast press technology $(n=18)$. (c) Eigenvector (second and third principal components) projection of the sparkling ciders and polypeptides selected $\left(\mathrm{P}_{1}, \mathrm{P}_{2}, \mathrm{P}_{3}, \mathrm{P}_{14}\right.$ and $\left.\mathrm{P}_{22}\right)$. Grouping 1 : sparkling ciders elaborated using $S$. cerevisiae strain $(n=14$; wine category, $\mathrm{W})$; grouping 2 : sparkling ciders elaborated using $S$. bayanus strain ( $n=15$; cider category, C).

ter (such as $\mathrm{P}_{36}, \mathrm{P}_{37}$, and $\mathrm{P}_{39}$ ) and, probably, with higher molecular weight, in agreement with the results obtained by our research group (Blanco Gomis et al., 2007). In consequence, this observation 
is in accordance with the smooth weaker breakage of parenchyma cells in fruit produced with this press technology which could promote a lower extraction level of macromolecules of higher molecular weight.

\subsubsection{Sparkling ciders}

Principal component (PC) analysis was used to represent the five-dimensional data structure in a smaller number of dimensions in order to estimate the relationship between classes (yeast type used in the foam taking step) and selected variables (polypeptides: $\mathrm{P}_{1}, \mathrm{P}_{2}, \mathrm{P}_{3}, \mathrm{P}_{14}$, and $\mathrm{P}_{22}$ ), and to define the structure of the data.

Three PCs that accounted for $81.2 \%$ of the variance were chosen on the basis of Kaiser's criterion. Fig. 2c displays the projection on the second and third eigenvectors (46.5\% explained variance) of the sparkling ciders and polypeptides selected. As we can see, the most sparkling ciders belonging to class $C$ (S. bayanus strain) are related to $\mathrm{P}_{14}$ and $\mathrm{P}_{22}$ polypeptides.

\subsection{Modeling}

\subsection{1. "Natural" ciders}

Once we have well established the internal structure of the database we can use modeling techniques in order to compute models for classifying samples according to variation sources detected. By means of Bayesean analysis, the function of the probability density was estimated and a hyperellipsoid was constructed for each class or category with a critical Mahalanobis distance. Sensitivity $(1-\alpha)$ and specificity $(1-\beta)$ were computed for each model, which were related to first-class $(\alpha)$ and second-class $(\beta)$ errors. Four models were computed, namely: "good foaming quality" (G), "neutral or bad foaming quality" (NB), "slow press technology" (S), and "fast press technology" (F). For models G and NB the database used was 34 (objects) $\times 10$ (polypeptides), while for models $\mathrm{S}$ and $\mathrm{F}$ the database used was 34 (objects) $\times 11$ (eigenvectors).

The models constructed for classifying classes $G$ and NB had $100 \%$ of sensitivity, since the models recognized all the ciders belonging to each class. Specificities were $94.4 \%$ and $100 \%$ for G and NB classes, respectively, as $5.6 \%$ of ciders belonging to class NB were recognized by model $G$, but not one of the ciders belonging to category $\mathrm{G}$ was accepted by model NB. Correct classifications were $100 \%$.

Models computed for S and F categories presented 100\% sensitivity, $100 \%$ specificity, and classification exits were $100 \%$. In consequence, models computed are sufficiently feasible and robust for classifying ciders according to foaming quality and press technology.

\subsubsection{Sparkling ciders}

In order to classify sparkling ciders on the basis of the type of yeast strain used in foam taking process, we computed a Soft Independent Modeling of Class Analogy (SIMCA) normal range model with six principal components that accounted for 95.2 and $91.5 \%$ of the variance for the models $\mathrm{W}$ (wine strain) and C (cider strain), respectively, using a data matrix of 29 (sparkling ciders) $\times 22$ (polypeptides). Classification hits were $96.6 \%$, since only one sparkling cider belonging to $\mathrm{C}$ class is classified as belonging to $\mathrm{W}$ class. Sensitivities for the models were: $85.7 \%$ (W model) and $86.7 \%$ (C model); so, approximately, $14 \%$ of the samples belonging to each category were rejected by their own model. Specificities for the models were: $86.7 \%$ (W model) and $85.7 \%$ (C model), what implies that $13 \%$ of samples belonging to category $C$ are accepted by model $\mathrm{W}$, and $14 \%$ of the samples belonging to category $\mathrm{W}$ are accepted by the model $\mathrm{C}$.

\subsection{Partial least squares (PLS)}

\subsection{1. "Natural" ciders}

This analysis was used to evaluate correlations between foam parameters [criterion or response variables $(r=3), \mathrm{FH}, \mathrm{FS}$, and ST] and polypeptides ( $p=39$, predictor variables), with predictive purpose. Database consisted of a matrix of 34 (ciders) $\times 42$ (predictor and criterion variables). Significant latent variables (principal components) were computed maximizing cross-validated explained variance $\left(\mathrm{CVEV}_{r}\right)$ for each foam parameter $(r)$, using three groups for cancellation. At the same time, predictor variables $(p)$ were chosen by their weighted importance parameter $\left(I_{p}\right)$. Cut off value chosen for $I_{p}$ was 0.05 . With this criterion in mind, five predictor variables were selected, namely: $\mathrm{P}_{36}, \mathrm{P}_{7}, \mathrm{P}_{4}, \mathrm{P}_{6}$, and $\mathrm{P}_{37}$.

Table 2 shows the evaluated PLS parameters. As can be seen, FS and ST were the foam parameters with a higher correlation, computing multiple linear correlation coefficients higher than $73 \%$. The most relevant predictor variables were polypeptides $P_{36}$ and $\mathrm{P}_{7}$. As Bamforth (1985) described, foam stability (related to ST parameter) is influenced by surface elasticity, tension, and viscosity, being probably the proteins with high molecular weight (Blanco Gomis et al., 2007) and more hydrophobic the most appropriated for stabilizing film of bubbles, as polypeptide $\mathrm{P}_{36}$. More hydrophilic proteins, such as polypeptide $\mathrm{P}_{7}$, can also contribute to increase bubble average lifetime (related to FS parameter) by steric hindrance and electrostatic repulsions. The relationship between stability time of foam and proteins is not simple, since, polyphenols and other molecules can also to contribute to stabilize foams through hydrophobic interactions and hydrogen bonds (Sarker, Wilde, \& Clark, 1995).

Table 3 shows the mathematical equations that predict the Foam Stability height (FS) and foam Stability Time (ST) using a PLS model with two significant latent variables and five predictor variables (polypeptides); linear correlation coefficients computed were 0.800 and 0.823 , respectively. Therefore $64 \%$ and $68 \%$ of FS and ST variance, respectively, is explained by the regression model computed.

\subsubsection{Sparkling ciders}

Discriminant partial least squares analysis was used for differentiating sparkling ciders on the basis of the yeast type ( $\mathrm{W}$ and $\mathrm{C}$ classes) used in the foam taking process. Dependent or criterion variable was a binary response ( $\mathrm{Y}$ : 1 , if sample belonging to $\mathrm{W}$ class; Y: 2, if sample belonging to $C$ class), and the independent ones were polypeptides $(p=22)$. Database consisted of a matrix 29 (sparkling ciders) $\times 23$ (predictor and response variables). Predictor variables were selected by their weighted importance parameter, cut off value chosen for this parameter being 0.05 . With this criterion in mind the following polypeptides were selected: $\mathrm{P}_{1}$; $\mathrm{P}_{2} ; \mathrm{P}_{3} ; \mathrm{P}_{9} ; \mathrm{P}_{12} ; \mathrm{P}_{13} ; \mathrm{P}_{14} ; \mathrm{P}_{20} ; \mathrm{P}_{21} ;$ and $\mathrm{P}_{22}$.

In Table 4, are shown the PLS parameters for the binary response $(\mathrm{Y})$. The number of latent variables was selected in order to maximize cross-validated explained variance. With one latent variable was computed the maximum cross-validated explained

\section{Table 2}

PLS parameters for the response variables: FH, FS, and ST. CVEVmax: maximum crossvalidated explained variance; EV: explained variance; $R^{2}$ : multiple linear correlation coefficient.

\begin{tabular}{lllll}
\hline $\begin{array}{l}\text { Response } \\
\text { variable }\end{array}$ & $\begin{array}{l}\text { Number of significant } \\
\text { latent variables }\end{array}$ & CVEVmax (\%) & EV (\%) & $R^{2}(\%)$ \\
\hline FH & 1 & 37.4 & 46.1 & 47.7 \\
FS & 2 & 62.9 & 71.6 & 73.3 \\
ST & 2 & 66.9 & 74.3 & 75.9 \\
\hline
\end{tabular}


Table 3

Mathematical equations for predicting FS and ST values $(n=34)$ using a PLS model with two significant latent variables and five polypeptides.

\begin{tabular}{ll}
\hline Response variable & Equation \\
\hline FS & $\mathrm{FS}_{\text {predicted }}=0.727 * \mathrm{FS}_{\text {true }}+0.91$ \\
ST & $\mathrm{ST}_{\text {predicted }}=0.742 * \mathrm{ST}_{\text {true }}+4.88$
\end{tabular}

Table 4

PLS parameters of the response variable (Y). CVEV: cross-validated explained variance; EV: explained variance; $R^{2}$ : multiple linear correlation coefficient.

\begin{tabular}{lllll}
\hline Response variable & Number of latent variables & $\operatorname{CVEV}(\%)$ & $\operatorname{EV}(\%)$ & $R^{2}(\%)$ \\
\hline Y & 1 & 48.8 & 60.3 & 61.7 \\
Y & 2 & 40.8 & 65.4 & 67.9 \\
Y & 3 & 26.8 & 66.3 & 69.9 \\
\hline
\end{tabular}

variance (48.8\%), and the explained variance and multiple linear correlation coefficient computed were $60.3 \%$, and $61.7 \%$, respectively. The discriminant PLS model computed did not allow us to distinguish both classes with sufficiently feasibility.

\section{Acknowledgment}

We thank the research group of Food Technology of SERIDA for its assistance and supply of experimental ciders, the University of Oviedo for the financial support as a Ph.D. Grant, and the Ministry of Education and Science and "Sidra el Gaitero" industry for financial support (project reference AGL2001-0713).

\section{References}

Andrés-Lacueva, C., López-Tamanes, E., Lamuela-Raventós, R. M., Buxaderas, S., \& De la Torre-Boronat, M. C. (1996). Characteristics of sparkling base wines affecting foam behaviour. J. Agric. Food Chem., 44, 989-995.

Bamforth, C. W. (1985). The foaming properties of beer. J. Inst. Brew., 91, 370-383. Bikerman, J. J. (1938). The unit of foaminess. Trans. Faraday Soc., 34, 634-638.

Blanco Gomis, D., Expósito Cimadevilla, Y., Junco Corujedo, S., \& Gutiérrez Álvarez, M. D. (2003). Fractionation and characterization of soluble proteins from cider. Food Chem., 83, 507-513.

Blanco Gomis, D., Mangas Alonso, J. J., Junco Corujedo, S., \& Gutiérrez Álvarez, M. D. (2007). Cider proteins and foam characteristics: A contribution to its characterization. J. Agric. Food Chem., 55, 2526-2531.

Blanco Gomis, D., Mangas Alonso, J. J., Junco Corujedo, S., \& Gutiérrez Álvarez, M. D. (2009). Characterization of sparkling cider by the yeast type used in taking foam on the basis of polypeptide content and foam characteristics. Food Chem., 115, 375-379.

Bobe, G., Beitz, D. C., Freeman, A. F., \& Lindberg, G. L. (1998). Separation and quantitation of bovine milk proteins by reversed-phase high-performance liquid chromatography. J. Agric. Food Chem., 46, 458-463.

Brissonnet, F., \& Maujean, A. (1991). Identification of some foam-active compounds in champagne base wines. Am. J. Enol. Viticult., 42, 97-102.

Brissonnet, F., \& Maujean, A. (1993). Characterization of foaming proteins in a Champagne base wine. Am. J. Enol. Vitic., 44(3), 297-301.
Forina, M., Leardi, R., Armanino, C., \& Lanteri, S. (1988). An extendable package of programs for data exploration, classification, and correlation. Amsterdam: Elsevier.

Gallart, M., Tomás, X., Suberbiola, G., López-Tamames, E., \& Buxaderas, S. (2004) Relationship between foam parameters obtained by the gas-sparging method and sensory evaluation of sparkling wines. J. Sci. Food Agric., 84, 127-133.

García, M. J., Aleixandre, J. L., Álvarez, I., \& Lizama, V. (2009). Foam aptitude of Bobal variety in white sparkling wine elaboration and study of volatile compounds. Eur. Food Res. Technol., 229, 133-139.

González, L. M., \& González-Lara, R. (1993). Solid-phase extraction of soluble proteins in grape musts. J. Chromatogr. A, 655, 336-339.

González-Lara, R. Correa, I. Polo, M. C., Martín-Alvarez, P. J. \& Ramos, M. (1989). Classification of variety musts by statistical analysis of their electrophoresis protein pattern. Food Chem., 34, 103-110.

González-Lara, R., \& González, L. M. (1991). Analysis of the soluble proteins in grape musts by reversed-phase HPLC. Chromatographia, 32, 463-465.

Kinsella, J. E. (1981). Functional properties of proteins: Possible relationships between structure and function in foams. Food Chem., 7, 273-288.

Knuutinen, J., \& Harjula, P. (1998). Identification of fish species by reversed-phase high-performance liquid chromatography with photodiode-array detection. $J$. Chromatogr. B, 705, 11-21.

Mangas, J. J., Moreno, J., Rodríguez, R., Picinelli, A., \& Suárez, B. (1999). Analysis of polysaccharides in cider: Their effect on sensory foaming properties. J. Agric. Food Chem., 47, 152-156.

Moreno-Arribas, M. V., Cabello, F., Polo, M. C., Martín-Álvarez, P. J., \& Pueyo, E. (1999). Assessment of the native electrophoretic analysis of total grape-must proteins for the characterization of Vitis vinifera L. Cultivars. J. Agric. Food Chem. 47, 114-120.

Núñez, Y. P., Carrascosa, A. V., González, R., Polo, M. C., \& Martínez-Rodríguez, A (2006). Isolation and characterization of a thermally extracted yeast cell wal fraction potentially useful for improving the foaming properties of sparkling wines. J. Agric. Food Chem., 54, 7898-7903.

Picinelli Lobo, A., Fernández Tascón, N., Rodríguez Madrera, R., \& Suárez Valles, B. (2005). Sensory and foaming properties of sparkling cider. J. Agric. Food Chem., 53, 10051-10056.

Polo, M. C., Cáceres, I., Palop, L., Dizy, M., Pueyo, E., \& Martín-Álvarez, P. J. (1989) Study of the proteic fraction of grape musts by high performance liquid chromatography and electrophoretical techniques. Variety differentiation. In G Charalambous (Ed.), Proceedings of the 6th international flavor conference, Rethymnon, Crete, Greece (pp. 87-101). Amsterdam: Elsevier Science.

Robillard, B., Despuech, E., Viaux, L., Malvy, J., Vignes-Adler, M., \& Duteurtre, B. (1993). Improvements of methods for sparkling base wine foam measurements and effect of wine filtration on foam behaviour. Am. J. Enol. Viticult., 44, 387-392.

Rodríguez-Nogales, J. M., García, M. C., \& Marina, M. L. (2006). Development of a perfusion reversed-phase high-performance liquid chromatography method for the characterization of maize products using multivariate analysis. $J$ Chromatogr. A, 1104, 91-99.

Santoro, M. (1995). Fractionation and characterization of must and wine proteins Am. J. Enol. Viticult., 46, 250-255.

Sarker, D., Wilde, P., \& Clark, D. (1995). Control of surfactant-induced destabilization of foams through polyphenol-mediated protein-protein interactions. J. Agric Food Chem., 43, 295-300.

Schmitt, C. Sánchez, C., Desobry-Banon, S., \& Hardy, J. (1998). Structure and technofunctional properties of protein-polysaccharide complexes: A review. Crit. Rev. Food Sci. Nutr., 38(8), 689-753.

Trujillo, A. J., Casals, I., \& Guamis, B. (2000). Analysis of major ovine milk proteins by reversed-phase high-performance liquid chromatography and flow injection analysis with electrospray ionization mass spectrometry. J. Chromatogr. A, 870, 371-380.

Wilde, P. J., Husband, F. A., Cooper, D., \& Ridout, M. J. (2003). Destabilization of bee foam by lipids: Structural and interfacial effects. J. Am. Soc. Brew. Chem., 61(4), 196-202.

Zayas, J. F. (1997). Foaming properties of proteins. In functionality of proteins in Food. Berlin, Germany: Springer-Verlag. 